\title{
Effect of Teriflunomide on Cells From Patients With Human T-cell Lymphotropic Virus Type 1-Associated Neurologic Disease
}

Yoshimi Enose-Akahata, PhD, Nyater Ngouth, BS, Joan Ohayon, MSN, Matt Mandel, MD, Jeffrey Chavin, MD, Timothy J. Turner, PhD, and Steven Jacobson, PhD

Neurol Neuroimmunol Neuroinflamm 2021;8:e986. doi:10.1212/NXI.0000000000000986

\section{Abstract}

\section{Objective}

To test the hypothesis that teriflunomide can reduce ex vivo spontaneous proliferation of peripheral blood mononuclear cells (PBMCs) from patients with human T-cell lymphotropic virus type 1 (HTLV-1)-associated myelopathy/tropical spastic paraparesis (HAM/TSP).

\section{Methods}

PBMCs from patients with HAM/TSP were cultured in the presence and absence of teriflunomide and assessed for cell viability, lymphocyte proliferation, activation markers, HTLV-1 tax and HTLV-1 hbz messenger ribonucleic acid (mRNA) expression, and HTLV-1 Tax protein expression.

\section{Results}

In culture, teriflunomide did not affect cell viability. A concentration-dependent reduction in spontaneous proliferation of PBMCs was observed with $25 \mu \mathrm{M}$ (38.3\% inhibition), $50 \mu \mathrm{M}$ (65.8\% inhibition), and $100 \mu \mathrm{M}$ (90.7\% inhibition) teriflunomide. The inhibitory effects of teriflunomide were detected in both $\mathrm{CD} 8^{+}$and $\mathrm{CD} 4^{+} \mathrm{T}$-cell subsets, which are involved in the immune response to HTLV-1 infection and the pathogenesis of HAM/TSP. There was no significant change in HTLV-1 proviral load (PVL) or tax mRNA/Tax protein expression in these short-term cultures, but there was a significant reduction of HTLV-1 PVL due to inhibition of proliferation of $\mathrm{CD} 4^{+} \mathrm{T}$ cells obtained from a subset of patients with HAM/TSP.

\section{Conclusions}

These results suggest that teriflunomide inhibits abnormal $\mathrm{T}$-cell proliferation associated with HTLV-1 infection and may have potential as a therapeutic option in patients with HAM/TSP.
Correspondence

Dr. Jacobson

jacobsons@ninds.nih.gov

From the Viral Immunology Section (Y.E.-A., N.N., S.J.), National Institute of Neurological Disorders and Stroke, National Institutes of Health, Bethesda, MD; Joan Ohayon, Neuroimmunology Clinic (J.O.), National Institute of Neurological Disorders and Stroke, National Institutes of Health, Bethesda, MD; and Sanofi (M.M., J.C., T.J.T.), Cambridge, MA. 


\section{Glossary}

CFSE = carboxyfluorescein succinimidyl ester; $\mathbf{C M V}=$ cytomegalovirus; $\mathbf{E B V}=$ Epstein - Barr virus; $\mathbf{D H O D H}=$ dihydroorotate dehydrogenase; DNA = deoxyribonucleic acid; HD = healthy donor; HAM = HTLV-1-associated myelopathy; HTLV-1 = human T-cell lymphotropic virus 1; HPRT = hypoxanthine phosphoribosyl transferase; $\mathbf{I L}=$ interleukin; $\mathbf{m R N A}=$ messenger ribonucleic acid; PBMC = peripheral blood mononuclear cell; $\mathbf{P C R}=$ polymerase chain reaction; $\mathbf{P V L}=$ proviral load; $\mathbf{T h} \mathbf{1}=\mathrm{T}$ helper 1; TSP = tropical spastic paraparesis.

Human T-cell lymphotropic virus 1 (HTLV-1) is a retrovirus causing persistent infection in humans; a small subset of infected individuals develops HTLV-1-associated myelopathy/tropical spastic paraparesis (HAM/TSP). ${ }^{1,2}$ HAM/TSP is a chronic, progressive, neurologic disease characterized by progressive lower extremity weakness, spasticity, and bladder/bowel sphincter dysfunction. ${ }^{3}$ Currently, no therapy significantly modifies longterm disability associated with HAM/TSP. HTLV-1 proviral load (PVL) is significantly elevated in peripheral blood mononuclear cells (PBMCs) and CSF of patients with HAM/TSP compared with asymptomatic carriers. ${ }^{4,5}$ Chronically activated immune responses against HTLV-1 and infiltration of inflammatory cells into the CNS contribute to clinical disability and underlie the pathogenesis of HAM/TSP.

Teriflunomide is an oral immunomodulator approved to treat MS that inhibits de novo pyrimidine synthesis, which is crucial for rapid expansion of activated lymphocytes. Pyrimidine synthesis inhibition is a well-established strategy for treatment of autoimmune diseases such as MS and rheumatoid arthritis. ${ }^{6-8}$ Teriflunomide has been shown to inhibit proliferation and reduce the number of activated $\mathrm{T}$ and $\mathrm{B}$ cells. ${ }^{9}$ In addition, teriflunomide and its parent compound leflunomide have been shown to have antiviral activity against a broad range of viruses in vitro and in vivo in humans, ${ }^{10-13}$ suggesting they might attenuate abnormal immune activation in patients with inflammatory diseases associated with chronic viral infection.

In this study, we examined whether teriflunomide can reduce the spontaneous lymphoproliferative response in culture of PBMCs from patients with HAM/TSP ex vivo, which is the immunologic hallmark of individuals infected with HTLV-1. ${ }^{14,15}$

\section{Methods}

\section{Subjects}

A total of 12 patients, defined as having HAM/TSP by World Health Organization criteria, an HTLV-1-uninfected healthy donor (HD) volunteer screened at the NIH Clinical Center were evaluated in this report. In the patients, the mean age was 56.6 years, and the mean disease duration was 11.8 years. Patients with HAM/TSP were not being treated with any immunosuppressive agents at the time of PBMC collection.

\section{Cell Viability}

PBMCs of HDs and patients with HAM/TSP were isolated by centrifugation using lymphocyte separation media and were cryopreserved in liquid nitrogen until use. PBMCs were suspended in complete Roswell Park Memorial Institute medium supplemented with $5 \%$ human serum type $\mathrm{AB}, 100 \mathrm{U} / \mathrm{mL}$ penicillin, $100 \mu \mathrm{g} / \mathrm{mL}$ streptomycin sulfate, and $2 \mathrm{mM}$ L-glutamine and plated in 96-well round bottom microplates at $3 \times 10^{5}$ cells/ well with defined concentrations of teriflunomide $(0,1.5,6.25,25$, and $100 \mu \mathrm{M})$, chosen as a wider range of concentrations than published previously for testing cell viability. ${ }^{16}$ The cells were cultured at $37^{\circ} \mathrm{C} / 5 \% \mathrm{CO}_{2}$, and the cell viabilities were examined at $0,1,3$, and 5 days using a Muse cell analyzer (Millipore).

\section{Lymphoproliferation Assay}

Lymphoproliferation assay using $\left[{ }^{3} \mathrm{H}\right]$ thymidine was performed as described previously. ${ }^{17}$ PBMCs of HDs and patients with HAM/TSP were cultured in triplicate in 96-well round bottom microplates at $3 \times 10^{5}$ cells/well with defined concentrations of teriflunomide $(0,25,50$, and $100 \mu \mathrm{M})$, which are comparable to concentrations achieved in vivo in pharmacokinetic studies of teriflunomide in patients with MS. The cells were pulsed after 3-5 days of culture with $1 \mu \mathrm{Ci}\left[{ }^{3} \mathrm{H}\right]$ thymidine. The average counts per minute from each of the wells were determined.

Lymphoproliferation assay using carboxyfluorescein succinimidyl ester (CFSE) (CellTrace CFSE cell proliferation kit; Invitrogen) was performed as described previously. ${ }^{18} \mathrm{PBMCs}$ were labeled with CFSE, according to the manufacturer's instruction, and plated at $3 \times 10^{5}$ cells/well in 96-well round bottom microplates with defined concentrations of teriflunomide $(0,25,50$, and $100 \mu \mathrm{M})$. After culture for 4 and 5 days, the cells were stained with antibodies against CD3, CD4, $\mathrm{CD} 8$, and CD25 (all from BD Biosciences). The data were acquired on an LSRII flow cytometer (BD Biosciences) and were analyzed using FlowJo 10.5 software (FlowJo LLC).

\section{HTLV-1 PVL}

HTLV-1 PVL was measured using droplet digital polymerase chain reaction (PCR) (Bio-Rad) as described previously. ${ }^{19}$ PBMCs of patients with HAM/TSP were cultured at $2 \times 10^{6}$ cells/well in 12-well plates with defined concentrations of teriflunomide $(0,25,50$, and $100 \mu \mathrm{M})$ and collected after culture for 1,3 , and 5 days. Deoxyribonucleic acid (DNA) was extracted from the PBMC using a DNeasy Blood and Tissue kit (Qiagen) according to the manufacturer's instructions. Primers and probes specific for HTLV-1 tax and human ribonuclease $\mathrm{P}$ protein subunit 30 were used. The duplex PCR amplification was performed in this sealed 96-well plate using a GeneAmp 9,700 thermocycler (Applied Biosystems). Following PCR amplification, the 96-well plate was transferred to a QX100 droplet reader 
Figure 1 Inhibition of Spontaneous Lymphoproliferation With Teriflunomide

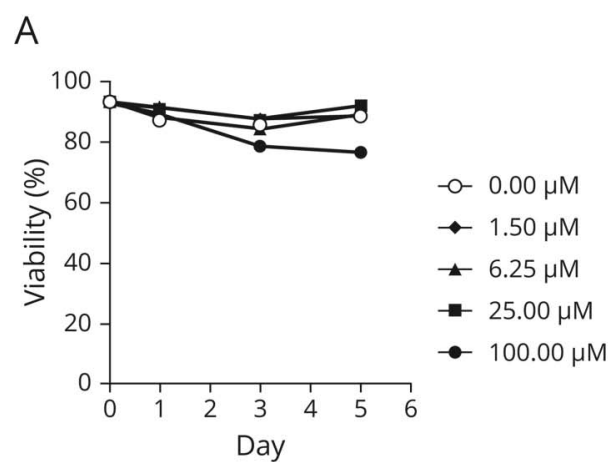

C

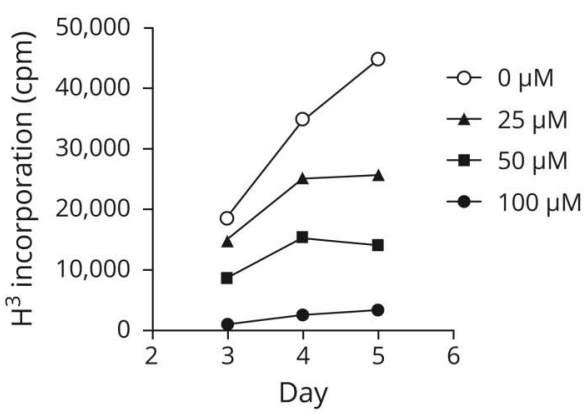

B

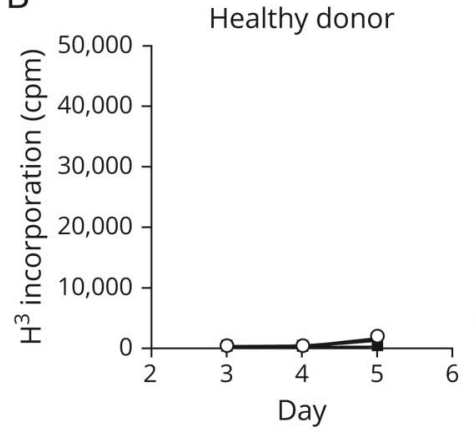

D

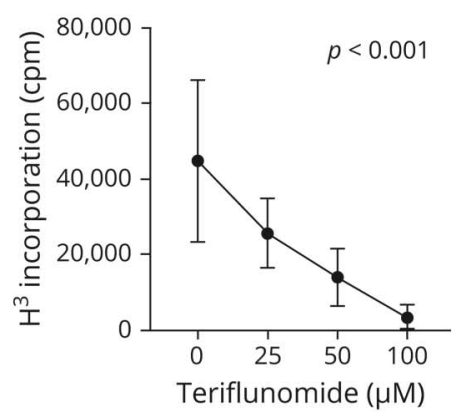

HAM \#1

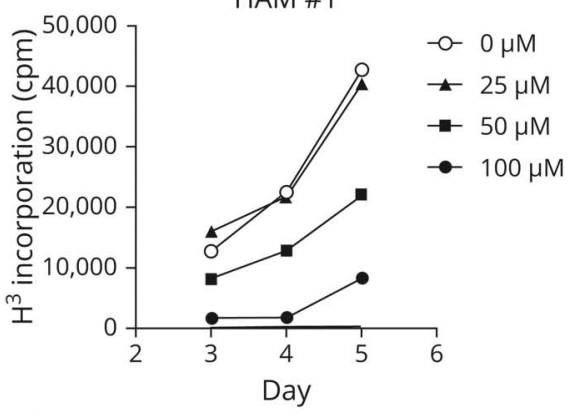

$E$

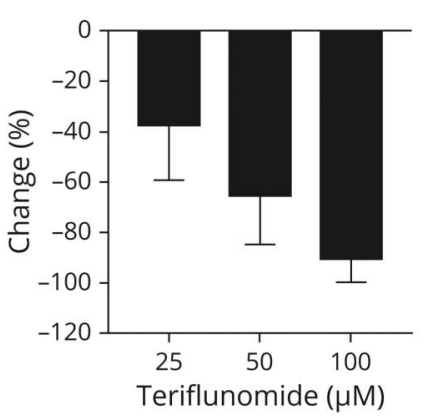

(A) Cell viability of PBMCs of an HD cultured with teriflunomide. (B) Spontaneous lymphoproliferation in cultured PBMCs of an HD (left graph) and a patient with HAM/TSP (HAM 1; right graph) with defined concentrations of teriflunomide. (C) Inhibition of spontaneous lymphoproliferation in cultured PBMCs of 12 patients with HAM/TSP with defined concentrations of teriflunomide. Each data point represents the mean of ${ }^{3} \mathrm{H}$ incorporation in a total of 12 patients with HAM/TSP. (D) Concentration-dependent inhibitory effect of teriflunomide on spontaneous lymphoproliferation in cultured PBMCs of 12 patients with HAM/ TSP at day 5. Each data point represents the mean with standard deviation. (E) Percent change of spontaneous lymphoproliferation in cultured PBMCs of 12 patients with HAM/TSP with teriflunomide compared with those without teriflunomide at day 5 . Each bar represents the mean with SD.

(Bio-Rad). For PVL calculation, QuantaSoft software version 1.3.2.0 (Bio-Rad) was used to quantify the copies/ $\mu \mathrm{L}$ of each queried target per well. All samples were tested in duplicate (a total of no less than 20,000 droplets), unless specified otherwise, and PVL is reported as the average of the 2 measurements.

\section{HTLV-1 tax/hbz Messenger Ribonucleic Acid Expression}

PBMCs of patients with HAM/TSP were cultured at $2 \times 10^{6}$ cells/well in 12-well plates with defined concentrations of teriflunomide $(0,25$, and $50 \mu \mathrm{M})$ and collected after 20 hours. RNA was extracted from fresh-frozen PBMCs or cultured PBMCs using the RNAeasy plus mini kit (Qiagen), and cDNA was synthesized from extracted RNA using a highcapacity cDNA reverse transcriptase kit (Applied Biosystems). Measurements of HTLV-1 tax and $h b z$ messenger ribonucleic acid (mRNA) were performed using ddPCR (Bio$\mathrm{Rad}$ ). The following primers and probes specific for HTLV-1 tax and HTLV-1 hbz were used: tax F (ATCCCGTGGAGACTCCT CAA); tax R (CCAAACACGTAGACTGGGTATCC); tax probe (6FAM-CCCCGCCGATCCCAAA-MGB); hbz F (AGAACG CGACTCAACCGG); hbz R (TGACACAGGCAAGCAT CGA); and hbz probe (6FAM-ATGGCGGCCTCAGGGCTMGB). Primers and probes specific for hypoxanthine phosphoribosyl transferase (HPRT) were used for normalization (Thermo Fisher Scientific). Normalized values of HTLV-1 tax
mRNA and $h b z$ mRNA expression were calculated using the following formula: HTLV-1 tax mRNA or $h b z$ mRNA = (the relative quantity of HTLV-1 tax mRNA or $h b z \mathrm{mRNA} /$ the relative quantity of $H P R T$ mRNA) $\times 100$. All samples were tested in duplicate, and HTLV-1 tax and $h b z$ mRNA expressions are reported as the average of the 2 measurements.

\section{Flow Cytometry}

PBMCs of patients with HAM/TSP were cultured at $3 \times 10^{5}$ cells/well in 96-well round bottom microplates with defined concentrations of teriflunomide $(0,25,50$, and $100 \mu \mathrm{M})$. After 20 hours, the cells were stained with antibodies for CD3, CD4, CD8, and CD25 (all from BD Biosciences). After treatment with fixation/permeabilization solution (eBiosciences), the cells were stained with antibody for Tax (Lt-4). The data were acquired on an LSRII flow cytometer (BD Biosciences) and were analyzed using FlowJo 10.5 software (FlowJo LLC).

\section{Statistics}

Repeated-measures 1-way ANOVA was used to compare spontaneous lymphoproliferation, $\mathrm{CD} 25^{+}$cells in the $\mathrm{CD} 4^{+}$ and $\mathrm{CD}^{+}{ }^{+}$T-cell populations, HTLV-1 PVL, and HTLV-1 tax mRNA and $h b z$ mRNA expressions at different concentrations of teriflunomide treatment. All statistical analysis was performed using Prism (GraphPad software). 
A. Teriflunomide
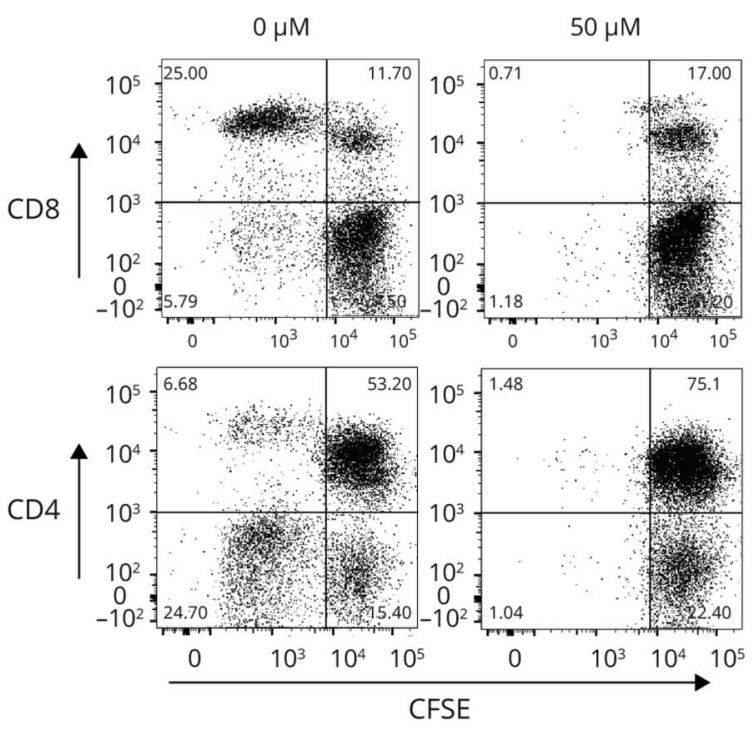

B

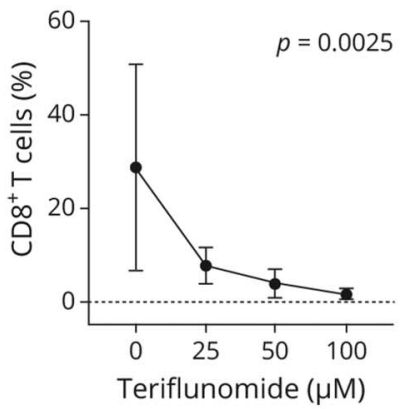

$\mathrm{D}$

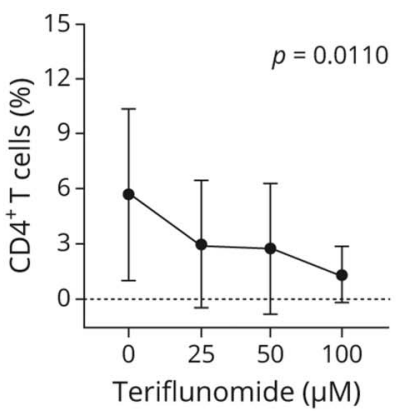

C

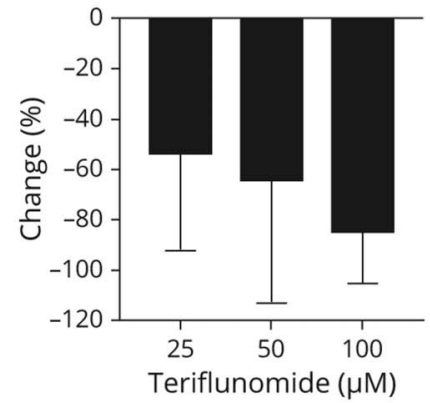

E

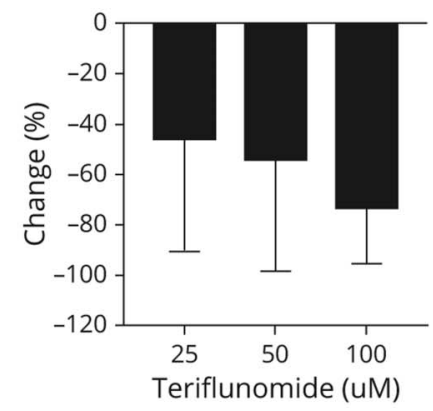

(A) Representative dot plots of CFSE staining in CD8 ${ }^{+}$and CD4 ${ }^{+}$T cells of a patient with HAM/TSP (HAM 1) with defined concentrations of teriflunomide after culture for 5 days. (B) Inhibitory effect of teriflunomide on CD8 ${ }^{+}$T-cell proliferation in cultured PBMCS of 12 patients with HAM/TSP at day 5 . Each data point represents the mean of CFSE staining with SD. (C) Percent change of CD8 ${ }^{+}$T-cell proliferation in cultured PBMCS of 12 patients with HAM/TSP with teriflunomide compared with those without teriflunomide at day 5 . Each bar represents the mean with SD. (D) Inhibitory effect of teriflunomide on CD4 ${ }^{+} \mathrm{T}$-cell proliferation in cultured PBMCs of 12 patients with HAM/TSP at day 5. Each data point represents the mean of CFSE staining with SD. (E) Percent change of CD4 ${ }^{+}$T-cell proliferation in cultured PBMCs of 12 patients with HAM/TSP with teriflunomide compared with those without teriflunomide at day 5 . Each bar represents the mean with SD. HAM = HTLV-1-associated myelopathy; PBMC = peripheral blood mononuclear cell; TSP = tropical spastic paraparesis.

\section{Standard Protocol Approvals, Registrations, and Patient Consents}

The study was reviewed and approved by the NINDS Institutional Review Board. All clinical samples used in this study were collected at NINDS under protocol \#98-N-0047. Before study inclusion, written informed consent was obtained from subjects in accordance with the Declaration of Helsinki.

\section{Data Availability}

All the data used for the article will be provided on request.

\section{Results}

\section{Teriflunomide Inhibited Spontaneous Lymphoproliferation of PBMCs From Patients With HAM/TSP}

Cell viability of PBMCs of a HD cultured with teriflunomide was examined, compared with that in the culture without teriflunomide. Teriflunomide $(0,1.5,6.25$, and $25 \mu \mathrm{M})$ did not affect cell viability during the culture for 5 days $(<3.6 \%$ difference; figure $1 \mathrm{~A}$ ). The cell viability was slightly lower at $8.2 \%$ and $13.7 \%$ at day 3 and day 5 for cultured PBMCs with $100 \mu \mathrm{M}$ teriflunomide, respectively (figure $1 \mathrm{~A}$ ).
To determine whether teriflunomide has an inhibitory effect on ex vivo spontaneous lymphoproliferation of patients with HAM/TSP, we examined lymphoproliferation in cultured PBMCs of patients with HAM/TSP compared with an HD with defined concentrations of teriflunomide. As shown in figure 1B, PBMCs of an HD did not spontaneously proliferate and therefore were not affected by the addition of teriflunomide in the culture (figure 1B; left graph). By contrast, spontaneous lymphoproliferation was detected in the PBMC culture of a patient with HAM/TSP (HAM 1) without any exogenous stimuli after day 3 (figure $1 B$; right graph). Incubation with defined $(25,50$, and $100 \mu \mathrm{M})$ concentrations of teriflunomide inhibited spontaneous lymphoproliferation in lymphocytes from this patient with HAM/TSP in a concentration-dependent manner (figure 1B; right graph). Group analysis of 12 patients with HAM/TSP also showed a concentration-dependent suppression in spontaneous lymphoproliferation in culture with teriflunomide between day 3 and day 5 (figure 1C). Group analysis of the effect of teriflunomide in HAM/TSP PBMC at a single time point (day 5) demonstrated a significant suppression of spontaneous lymphoproliferation in a concentration-dependent manner $(p<$ 0.0001; figure 1D). Compared with spontaneous lymphoproliferation without teriflunomide, the average percentage 

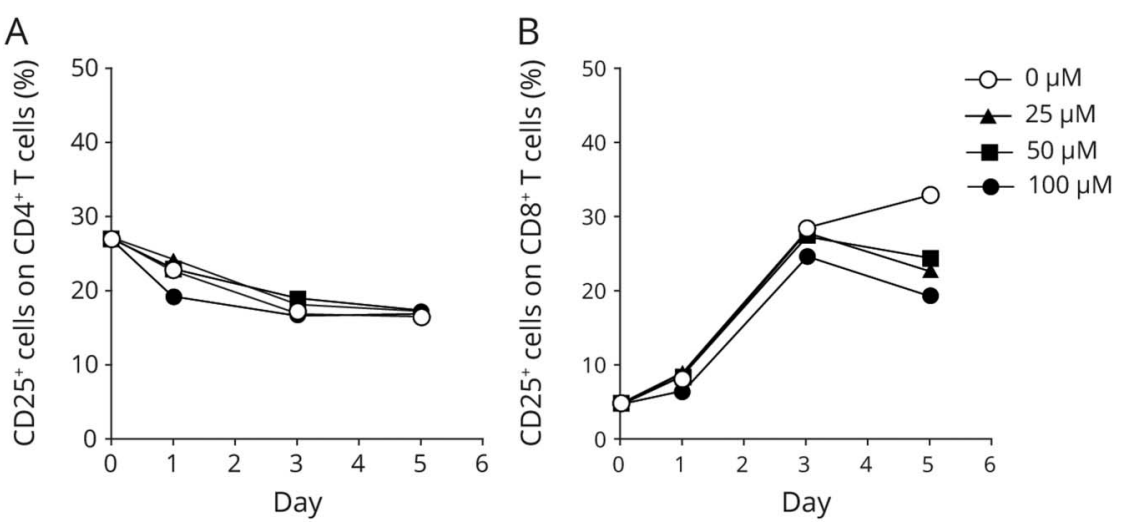

Frequency of $\mathrm{CD}_{2} 5^{+}$cells in the $\mathrm{CD} 4^{+} \mathrm{T}$-cell population (A) and in the $\mathrm{CD} 8^{+} \mathrm{T}$-cell population (B) of PBMCs from 9 randomly selected patients with HAM/TSP cultured with defined concentrations of teriflunomide. HAM = HTLV-1-associated myelopathy; $\mathrm{PBMC}=$ peripheral blood mononuclear cell; TSP = tropical spastic paraparesis.

decrease across all the patients with HAM/TSP was $38.3 \%$, $65.8 \%$, and $90.7 \%$ at 25,50 , and $100 \mu \mathrm{M}$ teriflunomide, respectively (figure $1 \mathrm{E}$ ). These results demonstrated that teriflunomide reduced ex vivo spontaneous lymphoproliferation in PBMCs of patients with HAM/TSP.

\section{Teriflunomide Inhibited Both $\mathrm{CD} 8^{+}$and $\mathrm{CD} 4^{+}$ T-Cell Proliferation of Patients With HAM/TSP} In patients with $\mathrm{HAM} / \mathrm{TSP}, \mathrm{CD}^{+} \mathrm{T}$ cells have been demonstrated to predominantly proliferate in ex vivo PBMC cultures. ${ }^{20}$ Given the inhibitory effect of teriflunomide on ex vivo spontaneous lymphoproliferation in patients with HAM/ TSP, we asked whether spontaneous lymphoproliferation of either $\mathrm{CD}^{+}$and/or $\mathrm{CD} 4^{+} \mathrm{T}$ cell is inhibited by teriflunomide in PBMC culture of patients with HAM/TSP. Figure 2A shows representative dot plots of spontaneous $\mathrm{CD}^{+}$and $\mathrm{CD} 4^{+} \mathrm{T}$-cell proliferation of a patient with HAM/TSP (HAM 1) in PBMC culture at day 5 with and without teriflunomide using CFSE. Both $\mathrm{CD}^{+}$and $\mathrm{CD}^{+}{ }^{+} \mathrm{T}$ cells showed spontaneous proliferation, although, as expected, $\mathrm{CD}^{+} \mathrm{T}$ cells proliferated to a greater extent than $\mathrm{CD}^{+} \mathrm{T}$ cells (figure $2 \mathrm{~A}$ ). After culture with teriflunomide $50 \mu \mathrm{M}$, both $\mathrm{CD}^{+}$and $\mathrm{CD} 4^{+}$ $\mathrm{T}$ cells showed a reduction in spontaneous lymphoproliferation (figure 2A). Group analysis of spontaneous $\mathrm{CD}^{+} \mathrm{T}$-cell proliferation in 12 patients with HAM/TSP showed a significant and concentration-dependent suppression in culture with teriflunomide at day $5(p=0.0025$; figure $2 \mathrm{~B})$. The average percent inhibition across all the patients with HAM/ TSP was $54.3 \%, 64.1 \%$, and $84.9 \%$ at 25,50 , and $100 \mu \mathrm{M}$ teriflunomide, respectively (figure $2 \mathrm{C}$ ), which was consistent with proliferation assay using $\left[{ }^{3} \mathrm{H}\right]$ thymidine (figure $1 \mathrm{E}$ ). Although $\mathrm{CD}^{+} \mathrm{T}$ cells of patients with HAM/TSP showed less proliferation than $\mathrm{CD}^{+} \mathrm{T}$ cells, spontaneous $\mathrm{CD}^{+}$ T-cell proliferation was also significantly suppressed with teriflunomide in a concentration-dependent manner (figure 2D). Compared with spontaneous lymphoproliferation without teriflunomide, the average percent inhibition across all the patients with HAM/TSP was $46.1 \%$, 54.2\%, and $73.2 \%$ at 25,50 , and $100 \mu \mathrm{M}$ teriflunomide, respectively (figure $2 \mathrm{E}$ ).
These results demonstrated that teriflunomide inhibited proliferation of both $\mathrm{CD}^{+}$and $\mathrm{CD}^{+} \mathrm{T}$ cells in ex vivo PBMC culture of patients with HAM/TSP.

\section{Teriflunomide Did Not Change an Activation Marker of Patients With HAM/TSP}

Patients with HAM/TSP have high levels of CD25 ( $\alpha$ chain of the interleukin (IL)-2 receptor) in T cells, particularly in $\mathrm{CD}^{+}$ T cells that contain high HTLV-1 PVL and increased expression of HTLV-1 tax mRNA. ${ }^{21}$ To determine whether teriflunomide has an effect on CD25 expression associated with HTLV-1 infection, we examined the frequency of $\mathrm{CD} 25^{+} \mathrm{T}$ cells in both $\mathrm{CD}^{+}$and $\mathrm{CD}^{+} \mathrm{T}$ cells in cultured PBMCs from patients with $\mathrm{HAM} / \mathrm{TSP}$ with defined concentrations of teriflunomide. In $\mathrm{CD}^{+} \mathrm{T}$ cells, there was no effect of teriflunomide on the frequency of $\mathrm{CD} 25^{+}$cells from patients with HAM/TSP through 5-day cultures compared with cultures without teriflunomide (figure $3 \mathrm{~A})$. Compared with $\mathrm{CD} 4^{+} \mathrm{T}$ cells, $\mathrm{CD} 8^{+} \mathrm{T}$ cells showed less $\mathrm{CD} 25$ expression before culture, but the frequency of $\mathrm{CD}_{25}{ }^{+}$cells increased in $\mathrm{CD}^{+} \mathrm{T}$ cells of patients with HAM/ TSP, consistent with an increase in spontaneous proliferation in this T-cell subset after culture (figure 3B). In the presence of teriflunomide, a reduced frequency of $\mathrm{CD} 25^{+}$cells in $\mathrm{CD}^{+}$ $\mathrm{T}$ cells was observed at day 5 , although this did not reach statistical significance (figure $3 \mathrm{~B}$ ). The average percent inhibition across all the patients with HAM/TSP was $30.9 \%, 26.0 \%$, and $41.1 \%$ at 25,50 , and $100 \mu \mathrm{M}$ teriflunomide, respectively (figure $3 \mathrm{~B})$. These results demonstrate that teriflunomide had minimal effect on the immune activation marker CD25 of patients with $\mathrm{HAM}$ /TSP during these short-term ex vivo PBMC cultures.

\section{Teriflunomide Did Not Change HTLV-1 mRNA Expression of Patients With HAM/TSP, But Inhibited Expansion of HTLV-1 Infection}

Because teriflunomide has been suggested to have potential broad-spectrum antiviral activity against several viruses such as cytomegalovirus (CMV) and Epstein-Barr virus (EBV), we next examined the effect of teriflunomide on HTLV-1 PVL, HTLV-1 mRNA, and HTLV-1 Tax protein expression in ex 


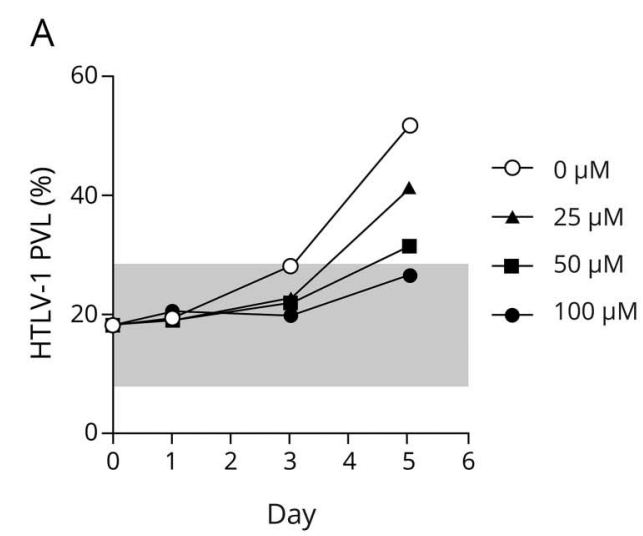

D

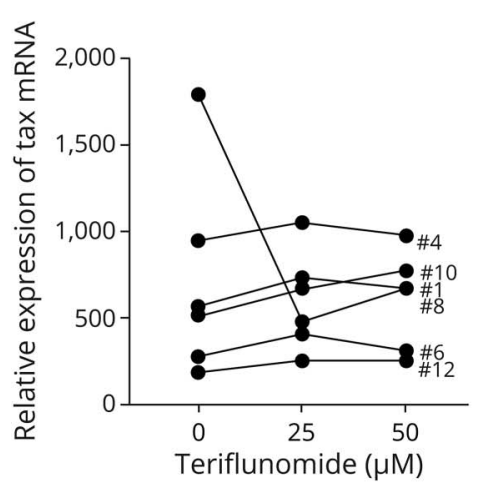

B

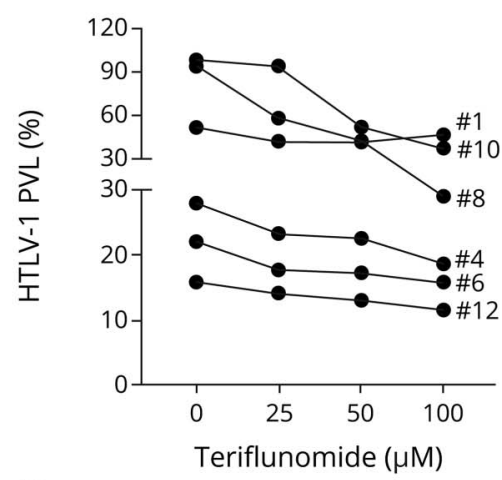

$E$

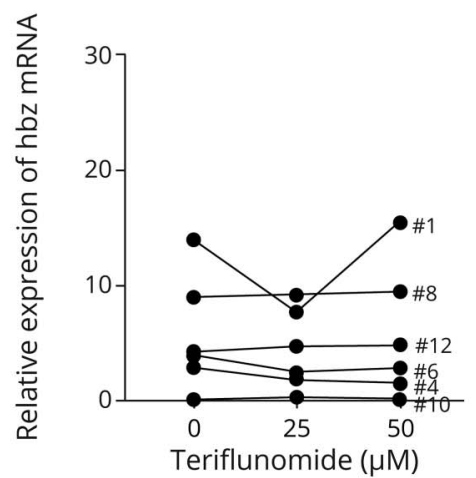

C

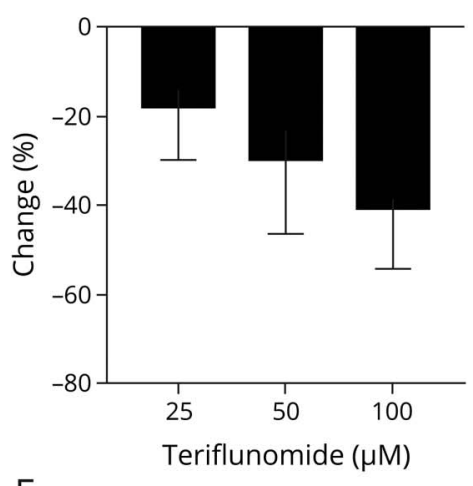

$\mathrm{F}$

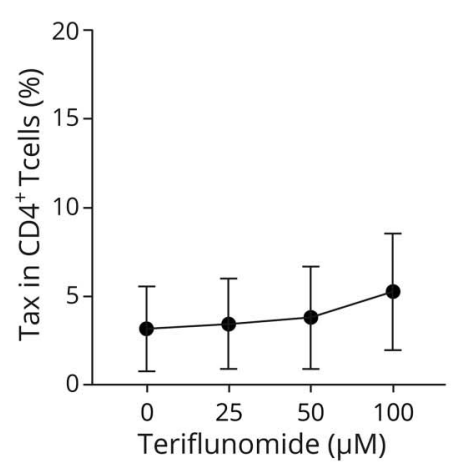

(A) Inhibition of HTLV-1 PVL in cultured PBMCs of 6 randomly selected patients with HAM/TSP with defined concentrations of teriflunomide. Each data point represents the mean of HTLV-1 PVL in a total of 6 patients with HAM/TSP. Shaded area represents the range of SD based on HTLV-1 PVL of total 6 patients with HAM/TSP at day 0. (B) Inhibitory effect of teriflunomide on HTLV-1 PVL in cultured PBMCs of 6 patients with HAM/TSP (patient numbers are indicated) at day 5 . (C) Percent change of HTLV-1 PVL in cultured PBMCs of 6 patients with HAM/TSP with teriflunomide compared with those without teriflunomide at day 5. Each bar represents the mean with SD. (D) HTLV-1 tax mRNA expression in PBMCs of 6 patients with HAM/TSP cultured with defined concentrations of teriflunomide for 20 hours. (E) HTLV-1 hbz mRNA expression in PBMCs of 6 patients with HAM/TSP cultured with defined concentrations of teriflunomide for 20 hours. (F) HTLV-1 Tax protein expression in CD4 ${ }^{+} T$ cells of cultured PBMCs from 12 patients with HAM/TSP with defined concentrations of teriflunomide for 20 hours. HAM = HTLV-1-associated myelopathy; HTLV-1 = human T-cell lymphotropic virus 1; PBMC = peripheral blood mononuclear cell; PVL = proviral load; TSP = tropical spastic paraparesis.

vivo PBMC culture of patients with HAM/TSP. HTLV-1 PVL in cultured PBMCs from 6 patients with HAM/TSP with defined concentrations of teriflunomide was examined. Group analysis showed that HTLV-1 PVL remained stable in PBMCs of a patient with HAM/TSP in the culture for 1 day with and without teriflunomide compared with HTLV-1 PVL before culture (figure 4A). Although HTLV-1 PVL gradually increased in PBMC culture without teriflunomide from day 3 to day 5, the increase of HTLV-1 PVL was inhibited with teriflunomide (figure 4A). After 5 days of culture, HTLV-1 PVL was reduced in PBMCs of patients with HAM/TSP in a concentration-dependent manner and approached statistical significance ( $p=0.0626$; figure $4 \mathrm{~B})$. Of interest, teriflunomide was able to inhibit HTLV-1 PVL in some patients with HAM/ TSP with high PVL (figure 4B; HAM 1, 8, and 10). Compared with HTLV-1 PVL in PBMC culture without teriflunomide, the average percent inhibition across all the patients with HAM/TSP was $18.4 \%, 30.2 \%$, and $40.9 \%$ at 25,50 , and $100 \mu \mathrm{M}$ teriflunomide, respectively (figure 4C).
In HAM/TSP, there is a spontaneous increase of HTLV-1 tax mRNA and HTLV-1 Tax protein expression in PBMCs after ex vivo culture without exogenous stimulators, which has been shown to peak at 12-24 hours in culture, although the HTLV1 PVL remains stable during this short period. ${ }^{22,23}$ To determine whether teriflunomide has an effect on HTLV-1 expression, we examined HTLV-1 tax and $h b z$ mRNA and HTLV-1 Tax protein in cultured PBMCs from patients with $\mathrm{HAM} / \mathrm{TSP}$ with defined concentrations of teriflunomide. As shown in figure $4 \mathrm{D}$, teriflunomide did not show any significant or concentration-dependent inhibition of HTLV-1 tax mRNA expression in 20-hour cultured HAM/TSP PBMC, except for the reduction of tax mRNA in 1 patient with HAM/ TSP (figure 4D). Teriflunomide also did not show any significant or concentration-dependent inhibition of HTLV-1 $h b z$ mRNA expression in 20-hour cultured HAM/TSP PBMC (figure 4E). In addition, Tax protein expression in $\mathrm{CD}^{+}$cells from cultured HAM/TSP PBMC was not significantly changed by treatment with teriflunomide (figure 4F). 
These results demonstrated that although teriflunomide did not directly affect HTLV-1 infection and expression in ex vivo PBMCs of patients with HAM/TSP in short-term cultures, teriflunomide reduced HTLV-1 PVL in ex vivo PBMCs of patients with HAM/TSP at day 5 when spontaneous lymphoproliferation was significantly inhibition in the culture.

\section{Discussion}

Chronically activated immune responses including T-cell proliferation and cytolytic activity of $\mathrm{CD}^{+} \mathrm{T}$ cells have been demonstrated to contribute to clinical disability and underlie the pathogenesis of HAM/TSP. ${ }^{24}$ In our study, the dihydroorotate dehydrogenase (DHODH) inhibitor teriflunomide reduced ex vivo spontaneous lymphoproliferation in PBMCs, which is a wellestablished measure of ex vivo T-cell activation in HAM/TSP. Inhibition of DHODH has been shown in clinical and preclinical studies to inhibit the proliferation of a number of cell types, but its modulation has not been previously shown to inhibit spontaneous lymphoproliferation in patients with HAM/TSP.

After culture of PBMCs from patients with HAM/TSP, T cells proliferate without exogenous stimulation, which is an immunologic hallmark of HAM/TSP. ${ }^{14,15}$ Mechanistically, this spontaneous lymphoproliferation is associated with an increased HTLV1 gene expression in PBMCs, which induce proliferation of HTLV-1-infected and/or activated T cells by the common $\gamma$ chain family of cytokines such as IL-2 and IL-15 in culture. ${ }^{20,25,26} \mathrm{~A}$ number of drugs and monoclonal antibodies have been reported to suppress inflammation and activation of lymphocytes, evidenced by inhibitory effects on spontaneous lymphoproliferation and cytokine expression in ex vivo PBMC culture of patients with HAM/TSP ${ }^{25,27-29}$ and have been used in clinical trials for patients with HAM/TSP. ${ }^{17,30,31}$ Proliferation of T cells in HAM/TSP may also be associated with the immunopathogenesis of this disease because antigen-specific $\mathrm{CD}^{+} \mathrm{T}$ cells have been shown to be elevated in peripheral blood, even higher in the CSF, of patients with HAM/TSP, and have been shown to be present in CNS lesions. ${ }^{5,32-34}$ Recently, teriflunomide has been reported to modulate oxidative phosphorylation and aerobic glycolysis in activated $\mathrm{T}$ cells via functional inhibition of complex III of the respiratory chain and preferentially reduce the proliferation of high-affinity $\mathrm{T}$ cells. ${ }^{6}$ It was therefore of interest to determine whether teriflunomide could also reduce the abnormal proliferation of HTLV1-specific $\mathrm{CD} 8^{+} \mathrm{T}$ cells in patients with HAM/TSP. In our study, teriflunomide significantly inhibited spontaneous $\mathrm{CD} 8^{+}$T-cell proliferation in PBMC culture of patients with HAM/TSP but did not affect cell viability or expression of the $\mathrm{T}$-cell activation marker $\mathrm{CD} 25$ in 5-day cultured PBMCs, consistent with a previous report. ${ }^{16}$ These results demonstrate that teriflunomide was able to inhibit abnormal proliferation of lymphocytes without killing these cells.

In addition to inhibition of $\mathrm{CD} 8^{+} \mathrm{T}$ cell proliferation, teriflunomide also inhibited the spontaneous proliferation of $\mathrm{CD}^{+} \mathrm{T}$ cells in PBMC cultures of patients with HAM/TSP. Both $\mathrm{CD}^{+}$and $\mathrm{CD}^{+} \mathrm{T}$ cells are involved in the immunologic regulation of HTLV-1 infection and in the inflammatory process associated with the pathogenesis of HAM/TSP. CD4 ${ }^{+}$ $\mathrm{T}$ cells are the predominant reservoir of HTLV- 1 and display a high expression of HTLV-1 viral products in patients with HAM/TSP. ${ }^{35,36}$ In addition, $\mathrm{CD}^{+} \mathrm{T}$ cells isolated from patients with HAM/TSP display a pattern of clonal expansion ex vivo in the absence of malignancy. ${ }^{26} \mathrm{HTLV}-1$ also infects $\mathrm{CD} 8^{+}$ $\mathrm{T}$ cells, albeit at lower frequency than $\mathrm{CD} 4^{+} \mathrm{T}$ cells, but the percentage of proliferating $\mathrm{CD} 8^{+} \mathrm{T}$ cells has been reported to be 2-5-fold higher than that of $\mathrm{CD}^{+} \mathrm{T}$ cells in ex vivo $\mathrm{PBMC}$ culture of patients with HAM/TSP. ${ }^{20,35}$ In HAM/TSP, T-cell proliferation is highly regulated and is associated with the expression of HTLV-1 Tax. ${ }^{20,25,37}$ HTLV-1 has developed numerous mechanisms to induce $\mathrm{T}$ cell proliferation in the absence of appropriate signals, such as transactivation of IL-2/ IL-2R $\alpha$ by HTLV-1 Tax. ${ }^{37}$ An additional disruptive effect of HTLV-1 Tax results from its impact on the ability of the cellcycle machinery to regulate DNA replication and cell division. It has been reported that the clonal expansion of HTLV-1infected T cells relies on 2 distinct mechanisms: HTLV-1 infection preventing cell death in $\mathrm{CD} 8^{+} \mathrm{T}$ cells while inducing $\mathrm{CD}^{+} \mathrm{T}$ cells into the cell cycle. ${ }^{26}$ Teriflunomide inhibits the action of DHODH via cell cycle arrest at the G1/S phase checkpoint and entry into the $\mathrm{G} 2 / \mathrm{M}$ phases without cell death, where HTLV-1 Tax promotes cell cycle progression. ${ }^{38,39}$ In HTLV-1-infected subjects, it has been reported that the median proliferation rate of $\mathrm{CD}^{+} \mathrm{CD}_{4} 5 \mathrm{RO}^{+}$and $\mathrm{CD}^{+}$ $\mathrm{CD}_{45 \mathrm{RO}^{+}} \mathrm{T}$ cells was $2.5 \%$ and $3.6 \%$ per day, respectively, and that the rate of $\mathrm{CD}^{+} \mathrm{CD}^{+} 5 \mathrm{RO}^{+} \mathrm{T}$ cell proliferation was significantly higher in patients with HAM/TSP than in asymptomatic carriers. ${ }^{40}$ In patients with MS treated with teriflunomide, a mild but consistent lymphopenia was observed due to the antiproliferative effets of teriflunomide. ${ }^{6,7}$ Of interest, distinct effects of teriflunomide treatment on different T-cell subsets have been reported in patients with MS, with an absolute reduction in T helper 1 (Th1) cells, but not Th2 or Th17 cells. ${ }^{6}$ Because the increase of HTLV-1-infected CD4 ${ }^{+}$ CCR4+ T cells with Th1 markers has been reported in patients with HAM/TSP, ${ }^{41}$ teriflunomide might be targeting Th1-type cells in these patients. Further studies will be required to understand how teriflunomide inhibits proliferation of both $\mathrm{CD} 4^{+}$ and $\mathrm{CD} 8^{+} \mathrm{T}$ cells in patients with HAM/TSP.

Teriflunomide also inhibited HTLV-1 PVL in relatively shortterm cultures of HAM/TSP PBMCs, although HTLV-1 expression was not affected by treatment with teriflunomide. Leflunomide/teriflunomide has been shown to have antiviral activity against a broad range of viruses, such as CMV, EBV, herpes simplex virus 1 , and $\mathrm{BK}$ polyomavirus, in vitro and in vivo in humans. ${ }^{10-13}$ Leflunomide has been shown to interfere with virion assembly of CMV but not to inhibit DNA synthesis, suggesting that this drug may potentially be used for its antiviral properties against $\mathrm{CMV}$ infection. ${ }^{13}$ Leflunomide has been increasingly used to treat human $\mathrm{CMV}$ and $\mathrm{BK}$ virus infection in organ transplant patients with immunosuppression. ${ }^{11}$ Recently, teriflunomide has been also reported to inhibit proliferation of EBV-transformed B cells as well as lytic 
EBV infection in vitro. ${ }^{10}$ Many viruses, and HTLV-1 in particular, replicate in dividing and proliferating cells in which these cells are the major reservoir for the virus. ${ }^{42}$ The effect of teriflunomide on inhibition of HTLV-1 proliferating cells would be consistent with its effect on reduction in HTLV-1 PVL. Of interest, HAM/TSP patients HAM 1, 8, and 10 showed dramatically increased levels of HTLV-1 PVL in the cultured PBMCs associated with higher percentages of proliferating $\mathrm{CD}^{+} \mathrm{T}$ cells and the highest levels of teriflunomide inhibition. Because HTLV-1 persistence depends to some extent on the clonal expansion of infected T cells in HTLV1-infected subjects, the inhibitory effects of teriflunomide on proliferation of HTLV-1-infected $\mathrm{T}$ cells may have therapeutic applications for HTLV-1-associated diseases.

Collectively, the results in this study demonstrated that ex vivo, teriflunomide reduced spontaneous lymphoproliferation of PBMCs, both in $\mathrm{CD}^{+}$and $\mathrm{CD}^{+}$T-cell subsets, from HAM/TSP patients. These results suggested that teriflunomide inhibited abnormal $\mathrm{T}$-cell proliferation associated with HTLV-1 infection. In addition to the ex vivo efficacy of teriflunomide, a better understanding of its mechanism of action will allow for future clinical use of teriflunomide in treatment of HTLV-1-associated neurologic disease.

\section{Acknowledgment}

The support of the NIH inpatient and outpatient neurology staff is acknowledged. Anti-Tax antibody (LT-4) was kindly provided by Dr. Yuetsu Tanaka, University of the Ryukyus, Okinawa, Japan. Critical review of the manuscript was provided by Jonathan Valenzano, PharmD, and Darren P. Baker, PhD, both of Sanofi. Editorial support was provided by Richard J Hogan, PhD, and Valerie P. Zediak, PhD, both of Eloquent Scientific Solutions. Teriflunomide is approved in many countries, including the United States and those of the European Union, for the treatment of relapsing forms of MS, including clinically isolated syndrome, relapsing-remitting MS, and active secondary progressive MS, depending on the local label. This material may contain information that is outside of the approved labeling in some countries.

\section{Study Funding}

This research was supported by the Intramural Research Program of the NINDS, NIH, and was funded by Sanofi.

\section{Disclosure}

Y. Enose-Akahata, N. Ngouth, and J. Ohayon, the NIH, have no conflicts of interest to disclose. M. Mandel, former employee of Sanofi. J. Chavin, employee of Sanofi. T. J. Turner, employee of Sanofi. S. Jacobson, the NIH, has no conflicts of interest to disclose. Go to Neurology.org/NN for full disclosures.

\section{Publication History}

Received by Neurology: Neuroimmunology \& Neuroinflammation August 7, 2020. Accepted in final form February 12, 2021.

\begin{tabular}{|c|c|c|}
\hline Name & Location & Contribution \\
\hline $\begin{array}{l}\text { Yoshimi } \\
\text { Enose- } \\
\text { Akahata, } \\
\text { PhD }\end{array}$ & $\begin{array}{l}\text { Viral Immunology Section, } \\
\text { National Institute of } \\
\text { Neurological Disorders and } \\
\text { Stroke, National Institutes of } \\
\text { Health, Bethesda, MD }\end{array}$ & $\begin{array}{l}\text { Conception and design of } \\
\text { the study, data acquisition, } \\
\text { data analysis, drafting the } \\
\text { manuscript text, and } \\
\text { preparing the figures }\end{array}$ \\
\hline $\begin{array}{l}\text { Nyater } \\
\text { Ngouth, } \\
\text { BS }\end{array}$ & $\begin{array}{l}\text { Viral Immunology Section, } \\
\text { National Institute of } \\
\text { Neurological Disorders and } \\
\text { Stroke, National Institutes of } \\
\text { Health, Bethesda, MD }\end{array}$ & $\begin{array}{l}\text { Data acquisition, data } \\
\text { analysis }\end{array}$ \\
\hline $\begin{array}{l}\text { Joan } \\
\text { Ohayon, } \\
\text { MSN }\end{array}$ & $\begin{array}{l}\text { Neuroimmunology Clinic, } \\
\text { National Institute of } \\
\text { Neurological Disorders and } \\
\text { Stroke, National Institutes of } \\
\text { Health, Bethesda, MD }\end{array}$ & Coordinated clinical work \\
\hline $\begin{array}{l}\text { Matt } \\
\text { Mandel, } \\
\text { MD }\end{array}$ & Sanofi, Cambridge, MA & $\begin{array}{l}\text { Conception and design of } \\
\text { the study and coordinated } \\
\text { clinical work }\end{array}$ \\
\hline $\begin{array}{l}\text { Jeffrey } \\
\text { Chavin, } \\
\text { MD }\end{array}$ & Sanofi, Cambridge, MA & $\begin{array}{l}\text { Data analysis, manuscript } \\
\text { preparation, and review }\end{array}$ \\
\hline $\begin{array}{l}\text { Timothy J. } \\
\text { Turner, } \\
\text { PhD }\end{array}$ & Sanofi, Cambridge, MA & $\begin{array}{l}\text { Conception and design of } \\
\text { the study }\end{array}$ \\
\hline $\begin{array}{l}\text { Steven } \\
\text { Jacobson, } \\
\text { PhD }\end{array}$ & $\begin{array}{l}\text { Viral Immunology Section, } \\
\text { National Institute of } \\
\text { Neurological Disorders and } \\
\text { Stroke, National Institutes of } \\
\text { Health, Bethesda, MD }\end{array}$ & $\begin{array}{l}\text { Conception and design of } \\
\text { the study, drafting the } \\
\text { manuscript text, and } \\
\text { preparing the figures }\end{array}$ \\
\hline
\end{tabular}

\section{References}

1. Gessain A, Barin F, Vernant JC, et al. Antibodies to human T-lymphotropic virus typeI in patients with tropical spastic paraparesis. Lancet 1985;2:407-410.

2. Osame M, Usuku K, Izumo S, et al. HTLV-I associated myelopathy, a new clinical entity. Lancet 1986;1:1031-1032.

3. Yamano Y, Sato T. Clinical pathophysiology of human T-lymphotropic virus-type 1-associated myelopathy/tropical spastic paraparesis. Front Microbiol 2012;3:389.

4. Nagai M, Usuku K, Matsumoto W, et al. Analysis of HTLV-I proviral load in 202 HAM/TSP patients and 243 asymptomatic HTLV-I carriers: high proviral load strongly predisposes to HAM/TSP. J Neurovirol 1998;4:586-593.

5. Nagai M, Yamano Y, Brennan MB, Mora CA, Jacobson S. Increased HTLV-I proviral load and preferential expansion of HTLV-I Tax-specific CD8+ T cells in cerebrospinal fluid from patients with HAM/TSP. Ann Neurol 2001;50:807-812.

6. Klotz L, Eschborn M, Lindner M, et al. Teriflunomide treatment for multiple sclerosis modulates $\mathrm{T}$ cell mitochondrial respiration with affinity-dependent effects. Sci Transl Med 2019;11:eaao5563.

7. O'Connor P, Wolinsky JS, Confavreux C, et al. Randomized trial of oral teriflunomide for relapsing multiple sclerosis. N Engl J Med 2011;365:1293-1303.

8. Mladenovic V, Domljan Z, Rozman B, et al. Safety and effectiveness of leflunomide in the treatment of patients with active rheumatoid arthritis. Results of a randomized, placebo-controlled, phase II study. Arthritis Rheum 1995;38:1595-1603.

9. Bar-Or A. Teriflunomide $\left(\right.$ Aubagio $^{\star}$ ) for the treatment of multiple sclerosis. Exp Neurol 2014;262(pt A):57-65.

10. Bilger A, Plowshay J, Ma S, et al. Leflunomide/teriflunomide inhibit Epstein-Barr virus (EBV)-induced lymphoproliferative disease and lytic viral replication. Oncotarget 2017;8:44266-44280.

11. Jung $\mathrm{YH}, \mathrm{Moon} \mathrm{KC}, \mathrm{Ha} \mathrm{JW}$, et al. Leflunomide therapy for BK virus allograft nephropathy after pediatric kidney transplantation. Pediatr Transpl 2013;17:E50-E54

12. Knight DA, Hejmanowski AQ, Dierksheide JE, Williams JW, Chong AS, Waldman WJ. Inhibition of herpes simplex virus type 1 by the experimental immunosuppressive agent leflunomide. Transplantation 2001;71:170-174.

13. Waldman WJ, Knight DA, Blinder L, et al. Inhibition of cytomegalovirus in vitro and in vivo by the experimental immunosuppressive agent leflunomide. Intervirology 1999;42:412-418.

14. Itoyama Y, Minato S, Kira J, et al. Spontaneous proliferation of peripheral blood lymphocytes increased in patients with HTLV-I-associated myelopathy. Neurology 1988;38:1302-1307. 
15. Jacobson S, Zaninovic V, Mora C, et al. Immunological findings in neurological diseases associated with antibodies to HTLV-I: activated lymphocytes in tropical spastic paraparesis. Ann Neurol 1988;23(suppl):S196-S200.

16. Li L, Liu J, Delohery T, Zhang D, Arendt C, Jones C. The effects of teriflunomide on lymphocyte subpopulations in human peripheral blood mononuclear cells in vitro. J Neuroimmunol 2013;265:82-90.

17. Oh U, Yamano $\mathrm{Y}$, Mora $\mathrm{CA}$, et al. Interferon-betala therapy in human T-lymphotropic virus type I-associated neurologic disease. Ann Neurol 2005;57: 526-534.

18. Enose-Akahata Y, Abrams A, Massoud R, et al. Humoral immune response to HTLV1 basic leucine zipper factor (HBZ) in HTLV-1-infected individuals. Retrovirology 2013;10:19.

19. Brunetto GS, Massoud R, Leibovitch EC, et al. Digital droplet PCR (ddPCR) for the precise quantification of human T-lymphotropic virus 1 proviral loads in peripheral blood and cerebrospinal fluid of HAM/TSP patients and identification of viral mutations. J Neurovirol 2014;20:341-351.

20. Sakai JA, Nagai M, Brennan MB, Mora CA, Jacobson S. In vitro spontaneous lymphoproliferation in patients with human $\mathrm{T}$-cell lymphotropic virus type I-associated neurologic disease: predominant expansion of CD8 $+\mathrm{T}$ cells. Blood 2001;98: 1506-1511.

21. Yamano Y, Cohen CJ, Takenouchi N, et al. Increased expression of human T lymphocyte virus type I (HTLV-I) Tax11-19 peptide-human histocompatibility leukocyte antigen $A^{*} 201$ complexes on CD4+ CD25+ T Cells detected by peptidespecific, major histocompatibility complex-restricted antibodies in patients with HTLV-I-associated neurologic disease. J Exp Med 2004;199:1367-1377.

22. Hanon E, Asquith RE, Taylor GP, Tanaka Y, Weber JN, Bangham CR. High frequency of viral protein expression in human $\mathrm{T}$ cell lymphotropic virus type 1-infected peripheral blood mononuclear cells. AIDS Res Hum Retroviruses 2000;16:1711-1715.

23. Yamano Y, Nagai M, Brennan M, et al. Correlation of human T-cell lymphotropic virus type 1 (HTLV-1) mRNA with proviral DNA load, virus-specific CD8(+) T cells, and disease severity in HTLV-1-associated myelopathy (HAM/TSP). Blood 2002;99:88-94.

24. Nozuma S, Jacobson S. Neuroimmunology of human T-lymphotropic virus type 1-associated myelopathy/tropical spastic paraparesis. Front Microbiol 2019;10:885.

25. Azimi N, Nagai M, Jacobson S, Waldmann TA. IL-15 plays a major role in the persistence of Tax-specific CD8 cells in HAM/TSP patients. Proc Natl Acad Sci U S A 2001;98:14559-14564.

26. Sibon D, Gabet AS, Zandecki M, et al. HTLV-1 propels untransformed CD4 lymphocytes into the cell cycle while protecting CD8 cells from death. J Clin Invest 2006;116:974-983.

27. Ju W, Zhang M, Jiang JK, et al. CP-690,550, a therapeutic agent, inhibits cytokinemediated Jak3 activation and proliferation of T cells from patients with ATL and HAM/TSP. Blood 2011;117:1938-1946.
28. Massoud R, Enose-Akahata Y, Tagaya Y, Azimi N, Basheer A, Jacobson S. Common gamma-chain blocking peptide reduces in vitro immune activation markers in HTLV 1-associated myelopathy/tropical spastic paraparesis. Proc Natl Acad Sci U S A 2015; 112:11030-11035.

29. Oh U, McCormick MJ, Datta D, et al. Inhibition of immune activation by a novel nuclear factor-kappa B inhibitor in HTLV-I-associated neurologic disease. Blood 2011;117:3363-3369.

30. Enose-Akahata Y, Oh U, Ohayon J, et al. Clinical trial of a humanized anti-IL-2/IL-15 receptor beta chain in HAM/TSP. Ann Clin Transl Neur 2019;6:1383-1394.

31. Lehky TJ, Levin MC, Kubota R, et al. Reduction in HTLV-I proviral load and spontaneous lymphoproliferation in HTLV-I-associated myelopathy/tropical spastic paraparesis patients treated with humanized anti-Tac. Ann Neurol 1998;44:942-947.

32. Jacobson S, Shida H, McFarlin DE, Fauci AS, Koenig S. Circulating CD8+ cytotoxic T lymphocytes specific for HTLV-I pX in patients with HTLV-I associated neurological disease. Nature 1990;348:245-248.

33. Levin MC, Lehky TJ, Flerlage AN, et al. Immunologic analysis of a spinal cord-biopsy specimen from a patient with human T-cell lymphotropic virus type I-associated neurologic disease. N Engl J Med 1997;336:839-845.

34. Matsuura E, Kubota R, Tanaka Y, Takashima H, Izumo S. Visualization of HTLV-1specific cytotoxic $\mathrm{T}$ lymphocytes in the spinal cords of patients with HTLV-1associated myelopathy/tropical spastic paraparesis. J Neuropathol Exp Neurol 2015; $74: 2-14$.

35. Nagai M, Brennan MB, Sakai JA, Mora CA, Jacobson S. CD8(+) T cells are an in vivo reservoir for human T-cell lymphotropic virus type I. Blood 2001;98:1858-1861.

36. Hanon E, Hall S, Taylor GP, et al. Abundant tax protein expression in CD4+ T cells infected with human T-cell lymphotropic virus type I (HTLV-I) is prevented by cytotoxic T lymphocytes. Blood 2000;95:1386-1392.

37. Waldmann TA. The shared and contrasting roles of IL2 and IL15 in the life and death of normal and neoplastic lymphocytes: implications for cancer therapy. Cancer Immunol Res 2015;3:219-227.

38. Cherwinski HM, McCarley D, Schatzman R, Devens B, Ransom JT. The immunosuppressant leflunomide inhibits lymphocyte progression through cell cycle by a novel mechanism. J Pharmacol Exp Ther 1995;272:460-468.

39. Gatza ML, Watt JC, Marriott SJ. Cellular transformation by the HTLV-I Tax protein, a jack-of-all-trades. Oncogene 2003;22:5141-5149.

40. Asquith B, Zhang Y, Mosley AJ, et al. In vivo T lymphocyte dynamics in humans and the impact of human T-lymphotropic virus 1 infection. Proc Natl Acad Sci U S A 2007; 104:8035-8040.

41. Araya N, Sato T, Ando H, et al. HTLV-1 induces a Th1-like state in CD4+CCR4+ T cells. J Clin Invest 2014;124:3431-3442.

42. Fan Y, Sanyal S, Bruzzone R. Breaking bad: how viruses subvert the cell cycle. Front Cel Infect Microbiol 2018;8:396. 


\title{
Neurology \\ Neuroimmunology \& Neuroinflammation
}

\author{
Effect of Teriflunomide on Cells From Patients With Human T-cell Lymphotropic \\ Virus Type 1-Associated Neurologic Disease \\ Yoshimi Enose-Akahata, Nyater Ngouth, Joan Ohayon, et al. \\ Neurol Neuroimmunol Neuroinflamm 2021;8; \\ DOI 10.1212/NXI.0000000000000986
}

This information is current as of April 9, 2021

\section{Updated Information \& Services}

References

Subspecialty Collections

Permissions \& Licensing

\section{Reprints}

including high resolution figures, can be found at: http://nn.neurology.org/content/8/3/e986.full.html

This article cites 42 articles, 13 of which you can access for free at: http://nn.neurology.org/content/8/3/e986.full.html\#\#ref-list-1

This article, along with others on similar topics, appears in the following collection(s):

All Immunology

http://nn.neurology.org//cgi/collection/all_immunology

Viral infections

http://nn.neurology.org//cgi/collection/viral_infections

Information about reproducing this article in parts (figures,tables) or in its entirety can be found online at:

http://nn.neurology.org/misc/about.xhtml\#permissions

Information about ordering reprints can be found online: http://nn.neurology.org/misc/addir.xhtml\#reprintsus

Neurol Neuroimmunol Neuroinflamm is an official journal of the American Academy of Neurology.

Published since April 2014, it is an open-access, online-only, continuous publication journal. Copyright

Copyright $\odot 2021$ The Author(s). Published by Wolters Kluwer Health, Inc. on behalf of the American

Academy of Neurology.. All rights reserved. Online ISSN: 2332-7812.

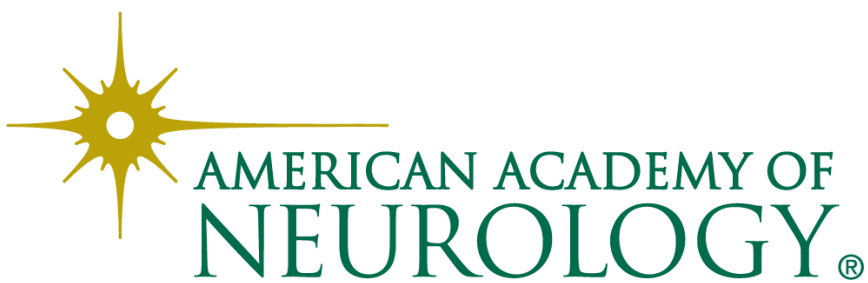

